Komunitas: Jurnal Pengembangan Masyarakat Islam

ISSN: 2086-3357 (p); 2540-9182 (e)

Vol. 11, No. 2 (2020), hal. 111-132 doi: 10.20414/komunitas.v9i2.2401

http://journal.uinmataram.ac.id/indeks.php/komunitas

\title{
STUDI KOMPARASI: TELAAH NASIONALISME DALAM ISLAM DAN KOMPARASI DENGAN PENDEKATAN BARAT
}

\author{
Wahyu Rozzaqi Ginanjar \\ zaqi.ginanjar@gmail.com \\ Magister Hubungan Internasional Universitas Muhammadiyah Yogyakarta
}

\begin{abstract}
Abstrak: Nasionalisme merupakan alat penghubung dalam usaha untuk mempersatukan beragam kelompok etnis ke dalam sebuah negara (state). Sebagai sebuah konsep atau gagasan, nasionalisme seringkali dipahami secara berbeda oleh para cendekiawan maupun tokoh pergerakan. Oleh karena itu, pandangan akan nasionalisme juga beragam, terdapat golongan yang menerima namun terdapat pula yang menolak konsep tersebut. Tulisan ini membahas tentang komparasi antara pemikiran politik Islam dengan pemikiran Barat mengenai nasionalisme. Diawali dengan mengelaborasi pemikiran politik Islam mengenai konsep ummah, kelompok etnis, definisi dari nation, pendekatan Islam klasik, serta pendekatan Islam modern yang didalamnya terdapat golongan yang mendukung serta yang menolak nasionalisme. Analisis komparasi dilakukan dengan membandingkan pemahaman dan pemikiran antara perspektif Islam dengan Barat mengenai nation, nasionalisme, serta menganalisis pandangan golongan cendekiawan muslim yang menerima nasionalisme dengan menggunakan teori imagined community oleh Benedict Anderson. Hasil komparasi menunjukkan terdapat perbedaan yang mencolok di antara perspektif Islam dengan Barat dalam cara pandangnya terhadap nasionalisme, namun hal tersebut tidak berarti bahwa nasionalisme tidak kompatibel bila digunakan dalam politik Islam.
\end{abstract}

(Abstract: Nationalism is known to be an idea that can be a medium for uniting various ethnic groups into a state. As a concept or idea, nationalism is often understood differently by scholars and movement figures. Therefore, the views on nationalism also vary, there are groups who accept, but there are also those who reject the concept. This paper discusses the comparison between Islamic political thought and western thinking about nationalism. Beginning with elaborating Islamic political thought about the concept of the ummah, ethnic groups, the definition of nation, the classical Islamic approach, and the modern Islamic approach in which there are various standpoints towards the notion of nationalism itself. Comparative analysis is done by comparing the understanding and thought between Islamic and Western perspectives on nation, nationalism, and analyzing the views of Muslim intellectuals who accept nationalism using the imagined community theory by Benedict Anderson. The comparison results show that there are striking differences between the perspectives of Islam and the West in their perspective of nationalism, but this does not necessarily mean that nationalism is incompatible when compared to Islamic political ideas.)

Kata Kunci : Bangsa, Islam, Nasionalisme, Negara

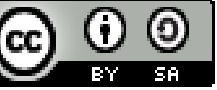

Creative Commons ShareAlike CC BY-SA: This work is licensed under a Komunitas Creative Commons Attribution-ShareAlike 4.0 International License

(http://creativecommons.org/licenses/by-na/4.0/) which permits remix, adapt, and build upon your work even for commercial purposes, as long as you credit us and license your new creations under the identical terms as spesified on the Komunitas: Jurnal Pengembangan Masyarakat Islam and Open Access pages. 
Wahyu Rozzaqi Ginanjar

\section{A. Pendahuluan}

Sebuah identitas, baik identitas sosial maupun identitas nasional terbentuk dari batas-batas sosial yang ditarik ke dalam teritorial dari suatu komunitas. Dalam mempelajari identitas politik dan sosial, hampir tidak memungkinkan bila kita tidak membahas mengenai struktur negara modern (the nation-state system), sekularitas dan politik nasionalisme. Dalam sebuah nation-state, loyalitas eksklusif dan tertinggi dari warga diklaim oleh negara. Seorang ilmuwan terkemuka mengatakan bahwa:

"nationalism takes the place of religion as the principle of governing all social and intellectual life." (Soper \& Fetzer, 2018)

Adapun ilmuwan lain mengambarkan nasionalisme sebagai sebuah agama. Di bawah sistem nation-state, minoritas terancam dari segala sisi (Ataman, 2003). Segala hak dan kepemilikan termasuk kehidupan mereka seringkali terancam karena sejarah telah menunjukkan bahwa nasionalisme lebih bersifat destruktif daripada bersifat konstruktif terutama bagi pihak yang lemah. Naqvi mengemukakan bahwa 'nasionalism directly leads to secularism', namun sekularisme mengubah makna dari minoritas (Naqvi, 1998). Dalam sebuah negara yang dibentuk berdasarkan sebuah agama, maka yang menjadi minoritas adalah pengikut dari agama-agama lain, sedangkan dalam term nasionalisme dan sekularisme, minoritas bisa berdasarkan ras, pilihan politik, atau wilayah tertentu (Sayegh, 2011).

Bila ditarik ke dalam konteks Muslim nation-state, tipe dominan dari batas-batas sosial turut mempengaruhi identitas warga muslim. Dengan adanya Muslim nationstate membuat warga muslim dilanda kebingungan atas identitas mereka, apakah loyalitas utama kepada ummah (sesama saudara muslim) ataukah kepada negara. Sistem nation-state mendominasi negara-negara yang sebagian besar warganya adalah populasi muslim, namun sampai saat ini belum ada paradigma identitas dominan yang mampu menghapus identitas keislaman dari masyarakat muslim. Adapun arah perkembangan dunia Islam terkini yakni mengarah kepada kebangkitan gerakan sosial dan politik Islam, mengacu pada hal tersebut masyarakat muslim mengingat kembali identitas ummah mereka (Owen, 1988).

Beberapa penelitian secara mendalam membahas mengenai bagaimana perlakukan negara-negara muslim terhadap minoritas yakni etnis non muslim, namun 
masih jarang ditemukan penelitian yang membahas mengenai pandangan Islam baik dalam perspektif klasik maupun modern terhadap etnis muslim yang menjadi minoritas dalam negara-negara muslim. Adapun penyebab dari hal tersebut yakni, pertama, seluruh kelompok etnis muslim dianggap sebagai satu 'bangsa' di dalam negara islam. Adanya studi dan penekanan terhadap diferensiasi etnis-etnis muslim pada negara islam bisa menyebabkan adanya gap dalam sebuah kelompok. Oleh karena itu, terminologi religius digunakan dalam semua sejarah negara-nagara islam lebih menekankan kepada agama itu sendiri. Yang kedua, perkembangan sejarah negara dan institusi muslim tidak membahas mengenai garis keetnisan. Sebagai contoh, negara Ayyobi yang didirikan oleh negarawan Kurdistan dan Jendral Saladin dianggap sebagai salah satu negara islam yang menentang tentara salib. IImuwan arus utama mengemukakan bahwa negara Ayyobi bukanlah negara Kurdistan melainkan sebuah negara Islam (Ataman, 2003).

Ketiga, institusi kekhalifahan menjadi bahan yang merarik bagi ilmuwan untuk meneliti negara tersebut secara keseluruhan. Penelitian-penelitian yang dilakukan berkonsentrasi pada kelompok etnis yang spesifik, namun beberapa peneliti tidak memunculkan argumen terkait hubungan di antara kelompok etnis muslim yang berbeda. Yang keempat, seluruh masyarakat muslim bersatu di bawah payung kekhalifahan hingga ditumbangkan oleh Kemal Ataturk di Turki pada 1924 baik secara teoretikal maupun formal.

Dalam era modern, kondisi etnis muslim pada negara-negara muslim mengalami perubahan yang signifikan dikarenakan berkembangnya nasionalisme dan munculnya nation-state. Prinsip-prinsip islam tetap bertahan dalam konstitusi dan hukum negara, namun roda pemerintahan yang seringkali berada di bawah pimpinan nasionalis dan sekuler justru merefleksikan prinsip sekuler serta nasionalisme ala barat (Owen, 1988). Hal tersebut berujung pada pengabaian peran agama dalam ranah sosial, ekonomi, serta politik. Hal ini menyebabkan persoalan yang fundamental pada negara yang memiliki etnis muslim minoritas sehubungan dengan identitas nasional dan kebudayaan masyarakat (Owen, 1988).

Pemikiran politik islam kian berkembang di negara-negara muslim saat ini. Ketika kita memperhatikan popularitas dan perkembangan kekuatan gerakan islam serta pemikiran dan basis landasannya, dapat kita temukan adanya kelompok yang tertindas dan lemah yang menjadi komposisi terbesar dari gerakan tersebut. 
Kelompok-kelompok yang cenderung dirugikan tersebut lebih memilih untuk memberikan dukungan kepada gerakan yang menentang penguasa, terutama yang berhaluan islam dan menentang rezim otoriter.

Dalam dunia global, sebagian besar konflik etnis berasal dari dua latar belakang yang berbeda, yakni makro nasionalisme dan mikro nasionalisme. Gerakan islam pada Muslim nation-state melahirkan solidaritas pan-islamic dalam dunia islam global. Tujuannya yakni bukan untuk menciptakan sebuah negara baru yang terdiri dari seluruh warga muslim di bahwa sebuah otoritas kekhalifahan., namun untuk membangun hubungan yang erat atau sebuah sistem konfederasi bagi negara-negara muslim (Formichi, 2010). Oleh karenanya, kebangkitan gerakan dan politik islam dapat dianggap sebagai sebuah perjuangan makro nasionalistik karena bertujuan untuk kepentingan kerjasama dan kordinasi yang semakin intens diantara negara tersebut. Adapun mengenai etnis, teori islam berdasar bahwa seluruh kelompok etnis muslim baik dalam hal kebahasaan, kebudayaan, teritorial, dan ras dianggap sebagai satu bangsa dan satu entitas politik. Inilah yang disebut dengan ummah (Ataman, 2003). Berdasarkan hal di atas, maka tujuan dari tulisan ini adalah untuk melakukan telaah mengenai komparasi antara nasionalisme berdasarkan pemikiran islam dengan nasionalisme yang digagas oleh pemikiran barat.

\section{B. Pembahasan}

\section{Konsep Ummah}

Islam bukanlah hanya agama melainkan sebuah jalan hidup bagi para muslim. Karenanya, agama dan negara dianggap sebuah kombinasi. Islam dijadikan sebagai kerangka berpikir dan berindak yang memberikan rasionalitas kepada warga muslim untuk menjalankan kebijakan negara. Segala macam persoalan kehidupan, baik persoalan individual, sosial, ekonomi, politik, nasional bahkan internasional untuk dipecahkan berdasarkan komitmen kepada Tuhan. Islam tidak memisahkan antara domain spiritual dan domain sekuler dalam kehidupan. Jamaluddin Afghani yang merupakan salah satu penggagas gerakan politik islam mengemukakan pendapatnya mengenai agama islam bahwa:

"which constitutes a nation, a culture or a civilization, forms its basis and foundation, and provides the most secure bond that holds it together" (Naqvi, 1998) 
Studi Komparasi: Telaah Nasionalisme...

Rashid al-Ghannouchi, seorang ilmuwan kontemporer menekankan bahwa:

"Islam as religion, as a faith, as a way of life, as a belief, as a social and political system is rooted in tauhid, the uniti of God and the unity of humankind'." (Saeed, 1999)

Konsep ummah berasal dari Nabi Muhammad pada abad ketujuh. Sekretaris umum pertama dari Liga Arab yakni Abd-al-Rahman Azzam menatakan bahwa 'the Muslims form a nation'(Naqvi, 1998). Nabi Muhammad merupakan warga negara pertama dan bertindak sebagai guru dan penunjuk. Nabi Muhammad mendirikan negara islam pertama dan apa yang disebut sebagai ummah setelah beliau melakukan hijrah dari Mekkah ke Madinah. Seacar alamiah, negara islam tersebut adalah bersifat universal, ia tidak mengenal batas geografis, bahasa maupun ras.

Mengenai penggunaannya dalam Al-Qur'an, ummah tidak terbatas pada arti ideologi melainkan perangkat kepercayaan di dalam komunitas, yakni sebuah sebuah kelompok yang didalamnya memiliki komitmen bersama dan sebuah komunitas yang bertahan seumur hidup, sebagai contoh Al-Qur'an menggambarkan pengikut Ibrahim sebagai sebuah ummah (Naqvi, 1998). Yusuf Ali mengemukakan bahwa, kata-kata seperti ras, bangsa dan golongan tidak bersesuaian dengan term ummah, adapun kata-kata yang merujuk padanya yakni agama, jalan hidup, persaudaraan, serta komunitas. Menurut Davutoğlu, dalam konteks teoretik:

'ummah, as the Islamic mode of social existence, is the basis of socio-political unity in Islamic political thought and practice'. (Ataman, 2003)

Nabi Muhammad mendirikan sebuah organisasi baru dengan identitas keislaman dimana sebelumnya orang-orang tergabung sebagai anggota sebuah suku dan berjanji setia dan mematuhi peraturan dan kebiasaan yang ada serta mendapatkan perlindungan dari suku tersebut. Meskipun sebagai bagian dari ummah berarti berpindah haluan atas loyalitas, ia tidak serta merta menghilangkan identitas kesukuan. Ummah hanya mengubah tatanan hirarki dari sebuah identitas individu dalam masyarakat. Identitas kesukuan tetap dianggap sebagai hal yang paling 
penting setelah identitas ummah. Sebagai bukti, mari kita merujuk pada Piagam Madinah. Piagam Madinah merupakan sebuah dokumen kesepakatan yang mendeklarasikan kumpulan warga muslim sebagai ummah yang disepakati oleh beberapa suku seperti penduduk asli Madinah dan imigran yang berasal dari Mekkah dimana piagam tersebut memberikan rekognisi bahwa seorang individu dapat memiliki lebih dari satu identitas bagi mereka yang memeluk Islam.

Setelah kematian Nabi, kepemimpinan kemudian diinstitusikan. Konsep ummah selalu diidentikkan dengan khilafah. Seorang khalifah atau imam kemudian diangkat sebagai penerus Nabi dan menjadi pemimpin ummah termasuk bagi warga muslim yang hidup di negara-negara non muslim. Hingga terjadinya sekularisasi khilafah oleh penerus Bani Umaiyyah, Khulafah al-Rashidin sebagai empat khalifah pertama dianggap sebagai implementasi ideal dari teori islam mengenai negara dan institusi khilafah.

\section{Konsep Minoritas dalam Islam}

Dalam Al-Quran digambarkan bahwa kehidupan manusia pada mulanya hanya terdiri atas satu komunitas karena permulaan umat manusia diawali dari sepasang laki-laki dan perempuan. Al-Qur-an menyebutkan bahwa Allah menciptakan manusia dari sepasang laki-laki dan perempuan, dan kemudian membuatnya terbagi menjadi berbangsa-bangsa dan bersuku-suku agar manusia saling mengenal satu sama lain. Difersifikasi atas manusia, bangsa, dan suku yang bervariasi memiliki tujuan untuk meningkatkan pengetahuan dan melengkapi satu sama lain melalui perbedaan manusia dan perbedaan sumber daya alam yang terdistribusi berbeda-beda pada setiap wilayah. Adapun pada model selanjutnya, pengelompokan semakin berkembang karena adanya ketidaksepahaman akan cara hidup satu sama lain.

Nationalities atau kebangsaan digambarkan sebagai cara yang berbeda dalam menjalani hidup menurut Islam. Oleh karena itu, seluruh warga muslim yang ada dianggap sebagai satu kesatuan, begitu pula dengan agama lainnya. Kata millah yang menjadi millet dalam bahasa Turki digunakan sebagai kata yang merujuk kepada nation dan digunakan oleh kekaisaran Ottoman bagi pembedaan orang-orang berdasarkan agama. Atas pemahaman tersebut, batas-batas sosial digambarkan beriringan dengan agama dalam sebuah negara Islam. satu-satunya minoritas yang 
ada pada masa tersebut adalah masyarakat non muslim yang bermukim di negara islam (Saeed, 1999).

Negara kemudian memberikan identitas sosial politik bagi setiap kelompok agama dan kebudayaan yang ada berdasarkan pendekatan ontologis. Identitas yang diberikan kepada non muslim dikenal sebagai dhimmi, yakni orang-orang yang dilindungi. Hal istimewa untuk dilindungi tersebut hanya diberikan kepada minoritas yang bertindak sebagai ahli kitab yakni Yahudi dan Nasrani. Namun, setelah ekspansi wilayah Islam, kaum Zoroaster, Hindu, Buddha, penyembah Harran dan kaum pagan Berbers dari Afrika Utara juga dianggap sebagai minoritas yang dilindungi (Ataman, 2003).

Hukum islam tidak mengenal perlakuan diskriminasi antara yang muslim dan yang bukan muslim. Kehidupan, kepemilikan, keamanan, kesejahteraan dan kehormatan orang-orang non muslim diproteksi sepenuhnya dalam hukum Islam (Ataman, 2003). Islam memberikan kebebasan bagi yang dianggap minoritas untuk hidup berdasarkan kebudayaan atau kebiasaan masing-masing, maka dari itu mereka memiliki hak individu maupun kolektif termasuk dalam hak beribadah sesuai dengan keyakinan serta otonomi yudisial. Osman mengemukakan bahwa, berdasarkan prinsip prinsip pengaturan dalam Islam, orang muslim harus memperlakukan orangorang non muslim dengan sikap adil dan kebaikan, selama orang-orang tersebut tidak berniat melakukan agresi dan permusuhan. Setiap dari mereka memiliki hak yang sama dengan orang muslim, termasuk hak untuk memilih, menjadi anggota parlemen, menjadi menteri, atau politisi. Posisi orang-orang non muslim di negara muslim tersebut membuat seorang pengamat dari Barat menjuluki sistem pluralistic yang dijalankan oleh negara muslim sebagai medieval religious democracy. Mawdudi juga menyebut sistem tersebut sebagai theo-democracy (Ataman, 2003).

Dalam hal perpajakan, minoritas non muslim membayar pajak yang disebut jizya. Hal tersebut bukanlah pajak tambahan karena warga muslim sendiri wajib membayar zakat kepada negara. Jizya merupakan pajak yang setara dengan zakat dan hanya diberlakukan bagi warga non muslim yang mampu. Beberapa pemimpin gerakan keislaman saat ini bahkan berpikiran bahwa jizya adalah hal yang tidak relevan untuk dilakukan lagi, dimana Al-Ganouchi menjelaskan bahwa jizya diasosiasikan dengan permintaan untuk menjadi anggota militer. Poinnya adalah 
bahwa terdapat sistem ekonomi yang seimbang antara warga muslim dan non muslim yang hidup di negara Islam.

\section{Kebijakan Negara terhadap Etnis}

Dalam sebuah kasus, Mehmet II (1451-1481) sebagai kasiar Ottoman membawa serta kepala gereja Armenia ke Istanbul untuk mendirikan gereja tidak lama setelah ia memperluas ekspansinya. Adapun sang anak Bayezid II (1481-1512) ketika berkuasa, menerima orang-orang Yahudi yang dideportasi dari Spanyol pada 1492 dan memberikan mereka tempat tinggal untuk hidup secara damai berdasarkan kebudayaan, serta mengimplementasikan aturan agama mereka (Riddell, 1982). Secara teori, negara Islam tidak mengintervensi urusan internal sebuah komunitas keagamaan (Ataman, 2003).

Sebuah pertanyaan kemudian muncul, hal apa yang kemudian menjadi batasan atas kebebasan budaya dan politik dari etnis minoritas yang terdapat dalam negara Islam? Yang pertama, bahwa selama kebudayaan dan tradisi ('urf) dianggap tidak menyimpang dari sumber hukum Islam yakni Al-Qur'an dan sunnah nabi, hadist, ijma (kesepakatan ulama) dan qiyas. Dalam hal ijma, semuanya berdasarkan pada kesepakatan ulama yang berasal dari etnis atau kelompok suku setempat. Hal ini disebabkan oleh adanya perbedaan entitas kebudayaan dari berbagai kondisi geografis yang berbeda. Oleh karena itu, terdapat perbedaan mengenai pemahaman Islam pada setiap kelompok etnis yang berujung pada perbedaan praktiknya (Lambton, 2013).

Yang kedua, term kebebasan (freedom) harus memiliki manfaat bagi kepentingan publik atau maslahat -'ammah yang berlaku baik bagi kelompok etnis muslim maupun etnis non muslim yang mana prinsip pemerintah yakni kepentingan publik diatas segalanya. Islam tidak hanya mengedepankan prinsip hukum/agama (siyasa dinniyya) namun ia juga mementingkan prinsip rasional (siyasa aqliyya) dalam memutuskan perkara kebaikan bagi semua. Ketiga, etnisitas yang beragam tidak berarti bahwa mereka saling berkompetisi atau bermusuhan satu sama lain. Bila hal tersebut terjadi, maka bisa menimbulkan adanya fragmentasi dan diskriminasi terhadap etnis tertentu. Kelompok etnis yang beragam adalah konsekuensi alamiah dari konsep universalisme Islam dan gagasan persatuan umat manusia. 
Keberagaman etnis yang ada harus diamini secara internal oleh setiap kelompok yang mengedepankan sikap kerjasama dan kordinasi (Lambton, 2013).

\section{Pendekatan Islam Klasik atas Etnis dan Nasionalisme}

Nabi Muhammad SAW dalam suatu khotbahnya mengatakan bahwa umat manusia diciptakan oleh Dzat yang satu, tidak ada yang lebih superior kedudukannya diantara Arab, Ajami (non-Arab), orang kulit hitam, ataupun orang kulit putih. Kemuliaan terletak hanya pada kesalehan. Piagam Madinah sebagai sebuah perjanjian pertama antara Islam dengan kelompok agama yang lain yakni kaum Yahudi yang ada di Madinah, mengembangkan budaya politik hidup secara berdampingan (co-existence). Berdasarkan piagam tersebut, kaum Yahudi hidup dengan menaati hukum Yahudi, serta kaum nasrani hidup dengan menaati hukum Kristen (Ataman, 2003).

Begitu pula dengan sejarah negara negara Islam terkemuka, seperti Dinasti Ummayyah, Andalusia, Dinasti Abbasiyah, serta kekaisaran Ottoman merupakan negara Islam yang multicultural dan multinasional. Kesemuanya memiliki keragaman budaya yang besar dengan adat istiadat, kebudayaan, serta hukum yang berbedabeda. Telah disebutkan pula sebelumnya bahwa Ottoman yang menggunakan sistem millet merupakan perkembangan dari teori Islam mengenai etnisitas yang paling mutakhir (Owen, 1988).

Kekaisaran Ottoman merupakan representasi terakhir dari insitusi kekhalifahan yang dijalankan berdasarkan prinsip Islam. Pengaturan etnisitas dan nasionalisme bersumber pada fondasi keagamaan. Berdasarkan sistem millet, nasionalitas keagamaan didahulukan daripada nasionalitas etnis. Kelompok etnis muslim memang dianggap sebagai satu kesatuan (one nation), namun setiap kelompol etnis muslim yakni etnis Turki, etnis Kurdi, etnis Arab, serta etnis Albania memiliki kebebasan kulturan serta administratif. Praktik desentralisasi baik secara sosial maupun politik dijalankan pada masa tersebut, sebagai hasilnya kelompok etnis muslim menjadi penerima manfaat terbesar dari sistem otonomi. Terdapat pemimpin-peminpin lokal yang diberi wewenang untuk mengirimkan pajak dan menyiapkan tentara bagi Sultan (Lambton, 2013).

Disamping itu, kelompok etnis dari agama yang berbeda dibagi berdasarkan agama atau denominasinya seperti gereja Yunani, gereja Katolik, atau gereja 
Armenia. Semuanya diterima dengan dianggap sebagai kesatuan (nation) yang berbeda-beda. Setiap 'nation' dijalankan sesuai dengan ajaran masing-masing dan memiliki pemimpin gereja yang berbeda. Pemaksaan untuk mengikuti ajaran Islam adalah terlarang dan pada praktiknya sangat jarang ditemukan. Hal ini selaras dengan apa yang disebutkan dalam Al-Qur'an bahwa tidak ada pemaksaan dalam beragama. Berdasarkan uraian di atas, tergambarkan dengan jelas bahwa perspektif Islam Klasik atas minoritas mengedepankan sikap liberal. Minoritas memiliki kebebasan untuk hidup berdasarkan kebudayaan dan agama yang mereka miliki bahkan memiliki kekebasan untuk mempunyai pemimpin sendiri dan dianggap sebagai sebuah 'nation'.

\section{Pendekatan Islam Modern atas Etnis dan Nasionalisme}

Konsep nasionalisme pertama kali digunakan oleh Ottoman dalam dunia Islam. Meluasnya pengaruh dari Barat di akhir abad ke-19 dan pada awal abad ke-20. Cendekiawan muslim seperti Mustafa Kemal dari Mesir, Namik Kemal dari Turki, serta Abul-Kalam Azad dari India mengatakan bahwa perpaduan antara nasionalisme dan Islam adalah mungkin dan hal tersebut merupakan solusi dari persoalan yang ada dalam dunia Islam. Adanya penjajahan di wilayah negara Islam dan terjadi secara meluas pada masa tersebut menyebabkan banyak orang muslim yang mendukung nasionalisme.

Nasionalisme sekuler dan ummah memainkan peran yang signifikan untuk menciptakan perlawanan terhadap kolonilasisasi Eropa di negara Islam. orang-orang muslim percaya bahwa nasionalisme sama dengan paham ummah sebagai ekspresi untuk menentang tirani, penjajahan, dan sebagai alat untuk menghapuskan opresi yang dilakukan oleh penguasa terhadap rakyat. Binnaz Toprak mengemukakan bahwa:

"in the case of countries under colonial rule with incipient nationalist movements, religion became a symbol of identity with the cultural heritage of the indigenous peoples which the colonial powers had attempted to destroy. Hence religion was used as an effective tool for social and political mobilization by nationalist leaders bent upon implanting a sense of pride in national culture and values".(Rajaee, 1988) 
Namun ketika dalam fase transisi, negara yang telah lepas dari tangan kolonial menghadapi persoalan sosial dan politik yang mengakibatkan terjadinya pemisahan antara golongan nasionalisme dan kelompok beragama pada Muslim nation-states. Sebagai contoh, pada awalnya warga muslim Ottoman mendukung the Committee of Unity and Progress yang merupakan nasionalis Turki, namun setelah golongan nasionalis berkuasa justru mereka menindas golongan muslim dan etnis non muslim lainnya yang menyebabkan adanya perlawanan dan revolusi pada 1909 melawan golongan nasionalis (Ataman, 2003).

Beberapa dekade selanjutnya, kelompok etnis muslim mendukung gerakan nasionalis dari Kemal Atatürk yang mengkalim untuk mempertahankan tanah kaum muslim dan populasinya dalam menentang invasi Inggris, Perancis, dan terutama Yunani dalam Perang Kemerdekaan pada 1919-1923. Ketika gerakan nasionalis tersebut menuai keberhasilan, mereka menolak akan identitas kelompok muslim seperti etnis Kurdi, etinis Laze, serta Arab dan gerakan perlawanan etnis terlambat dalam merespon kebangkitan nasionalis tersebut.

Pemahaman akan etnisitas dan nasionalisme di kalangan cendekiawan muslim modern terbagi menjadi dua yakni golongan yang menolak (the rejectionist) sepenuhnya dan golongan yang menerima (conformist) beberapa model nasionalisme yang dipahami berdasarkan prinsip Islam (Riddell, 1982). Golongan yang pertama yakni the rejectionist. sebagian besar cendekiawan muslim pada abd ke-20 menolak pandangan nasionalisme yang didasarkan pada prinsip Islam. Beberapa penolakan terhadap nasionalisme dapat dilihat melalui beberapa contoh sebagai berikut; Hasan Al-Bana sebagai pendiri dan pemimpin gerakan Islam terbesar di dunia yang berpusat di Mesir mengemukakan bahwa nasionalisme merupakan musuh paling berbahaya bagi gerakan Islamisme; Said Hawwa yang merupakan seorang cendekiawan muslim Suriah mengatakan bahwa:

'ethnic affiliation must have no impact upon the contents of one's belief, perseptions, and mores. This grave error ends up making nationalism a substitute for Islam' (Riddell, 1982)

Adapun organisasi semi pemerintah di Saudi Arabia yakni the Muslim World League (Rabitat al Alam al-Islami) menyetujui untuk mendukung Islam dan melawan 
konsiderasi nasionalistik (Haddad, 1983). Di bawah pemerintahan Raja Faisal, organisasi tersebut berjuang melawan nasionalisme Arab milik Nasser. Sementara di Palestina, Hamas dan kelompok Jihad Islam sebagai representasi golongan politik Islam telah berkembang sebagai reaksi atas the Palestine Liberation Organization yang merupakan golongan nasionalisme sekuler (Riddell, 1982).

Pada wilayah Asia Tenggara juga terjadi hal yang demikian. Di Pakistan misalnya, Muhammad Ali Jinnah menolak nasionalisme dan mendeklarasikan bahwa warga muslim India yang berasal dari berbagai latar etnis yang berbeda adalah satu nation. Mantan presiden Pakistan lainnya yakni Zia ul-Haq menekankan bahwa:

"Islam does not recognize any geographical limits dividing its followers. Muslims are Muslims, regardless of whether they are also Ajami, Arab, Pakistani, or Russian. Nationality is irrelevant within the ummah, within the universal brotherhood of Islam of Commonwealth of Muslim nations." (Haddad, 1983)

Begitu juga dengan golongan Syiah dimana Ayatullah Khomeini seorang cendekiawan syiah terkemuka dan pemimpin revolusi Islam Iran pada 1979 menganggap bahwa nasionalisme sebagai the source of all misfortunes of Muslims. Those who wish to revive nationalism are confronting Islam. (Naqvi, 1998)

Syiah mengklaim bahwa nasionalisme adalah penyebab atas diskriminasi dan eksploitasi kelompok-kelompok yang lemah. Dalam sebuah seminar yang membahas tentang 'The Impact of Nationalism on the Ummah' yang digelar di London pada 31 Juli hingga 3 Agustus 1985 oleh organisasi pro Iran yang berpusat di Inggris, para pemimpin gerakan keislaman dan negara Islam golongan syiah, menyatakan bahwa mereka adalah penentang dari sentiment-sentimen nasionalisme (Naqvi, 1998)

Adapun golongan kedua adalah golongan the conformist. Beberapa cendekiawan muslim menerima pandangan nasionalisme seperti Said Nursi, seorang cendekiawan muslim pada awal abad ke-20 yang berasal dari etnis Kurdi dan sekolah agama tradisional. Dalam tulisannya, ia menjabarkan bhawa nasionalisme memiki dua konteks yakni positif dan negatif. Nasionalisme positif adalah etnisitas dalam konteks religi, dimana nasionalisme yang kompatibel dengan agama. Hal tersebut 
dapat dipahami sebagai keragaman etnis dan budaya. Nasionalisme positif tersebut melahirkan realitas sosial dimana tumbuh kerjasama dan solidaritas, memperbesar keuntungan bersama, serta menumbuhkan persaudaraan antar muslim. Sekitar tahun 1910, Nursi disidang secara militer dan menegaskan bahwa nasionalisme Islam adalah satu satunya kebangsaan yang ia miliki dan nengatakan bahwa ia mengevaluasi segala sesuatu berdasarkan prinsip Islam (Zubaida, 2004).

Adapun nasionalisme negatif menurut Nursi adalah nasionalisme yang rasis, kompetitif, bermusuhan dengan bangsa lain, serta yang menolak lembaga dan nilainilai Islam yang ia anggap sebagai European disease. Nasionalisme negatif tumbuh dengan cara merugikan yang lain. Nursi menawarkan solidaritas Islam sebagai satusatunya cara untuk mencegah penjajahan di dunia Islam. la berargumen bahwa Islam tidak menerima kesejahteraan, keamanan, serta perkembangan kelompok etnis muslim yang mengorbankan kelompok etnis lainnya (Zubaida, 2004).

Selanjutnya, Fazlur Rahman seorang Profesor Studi Islam di Universitas Chicago dan mantan menteri pendidikan Pakistan. la juga membuat klasifikasi yang disebut sebagai nasionalisme sosial dan nasionalisme politik. Rahman mengemukakan bahwa keterlibatan dalam persatuan suatu kelompok harus diutamakan daripada keterlibatan dalam kesetiaan pada negara. la mengemukakan bahwa:

"...the Turkish or Egyptian peasant can be nationalist, experiencing a sense of common ties of culture, language, and history with other Turks or Egyptians, without losing the sense of belonging to a greater Islamic whole. But when he becomes a political nationalist, his loyalty and identity become secular and clash with the Islamic ideal... As long as the ideology that puts the nation-state above everything else is avoided, it is possible to have a multi-state system that is compatible with the larger loyalty to Islam." (Owen, 1988)

Nasionalisme positif milik Nursi dan nasionalisme sosial milik Rahman identik dengan pendekatan pluralisme yang diusulkan oleh pandangan Islam Klasik ataupun golongan rejectionist modern. 
Wahyu Rozzaqi Ginanjar

\section{Nasionalisme Tradisional: Primordial dan Instrumental}

Dalam memahami Nasionalisme dalam perspektif barat, terdapat dua pandangan tradisional terkait nasionalisme, yaitu nasionalisme primordialis dan nasionalisme instrumentalis. Bagian ini akan membahas lebih lanjut terkait dua perspektif tersebut.

Pada perspektif pertama, yaitu perspektif primordialisme, menganggap bahwa etnisitas manusia terjadi secara organik dan terbentuk seiring berjalannya waktu. Dalam beberapa dekade terakhir aliran pemikiran ini melahirkan dua pendekatan dalam melihat nasionalisme. Dua pendekatan tersebut ialah primordialisme sosiobiologis dan primordialisme kultural.

Pendekatan primordialisme sosiobiologis seringkali dikaitkan dengan temuantemuan Van den Berghe. Menurut van den Berghe, relasi sosial dan keterikatan antar individu dapat dijelaskan melalui kedekatan genetik satu sama lain (van Den Berghe, 1987). Dalam hal ini, individu-individu dalam kelompok etnis tertentu mencoba untuk mewariskan gen mereka kepada keturunannya secara langsung atau tidak langsung melalui praktek endogami (van Den Berghe, 1987). Hal tersebut didorong atas dasar keyakinan kolektif suatu kelompok etnis untuk mempertahankan kemurnian etnisitas mereka (van Den Berghe, 1987). Melalui perndekatan ini, kita dapat melihat bahwa dalam beberapa kelompok sosial tertentu nasionalisme seringkali didefinisikan dengan genealogi ras dan etnis. Implikasi dari hal tersebut yakni konsep nasionalisme tersebut menjadi sangat ekslusif terhadap karakteristik biologis yang spesifik, seperti ras, etnis, atau warna kulit (Conversi, 1995).

Perspektif yang kedua ialah perspektif primordial kultural. Perspektif ini sering dikaitkan dengan pandangan Clifford Geertz. Clifford Geertz berpendapat bahwa manusia memiliki keterikatan primordial terhadap atribut sosial yang bersifat "given". Atribut sosial yang bersifat "given" tersebut merujuk kepada banyak hal, seperti; ikatan kenisbatan, bahasa, adat-istiadat, kepercayaan dan banyak hal lainnya (Geertz, 1973). Hal-hal tersebut pada perjalanannya memiliki dampak terhadap individu yang lahir di dalamnya, yang mana melahirkan koersifitas kultural yang memiliki kemampuan untuk memaksa individu-individu di dalamnya untuk terikat kepada atribut-atribut yang telah disebutkan sebelumnya (Geertz, 1973). Proses tersebut yang pada akhirnya melahirkan ikatan primordial antar individu di dalamnya, yang mana pada praktiknya memiliki atribut yang berbeda antara satu kelompok sosial 
dengan kelompok sosial lainnya. Merujuk kepada pandangan Geertz, ia tidak berpendapat bawa atribut-atribut sosial tersebut bersifat primordial, melainkan keterikatan yang dimiliki oleh individu-indvidu di dalamnya yang kemudian menjalankan praktik-praktik primordialisme (Geertz, 1973). Keterikatan tersebut sering kita temui pada pembahasan terkait kelompok etnis, yang mana kemudian dapat menjelaskan perilaku beberapa individu sangat antusias tentang diskursus etnisitas, baik dalam konteks positif maupun negatif.

Selain pandangan primordialisme, terdapat pandangan lain dalam melihat nasionalisme, yaitu pandangan instrumentalisme. Dalam hal ini, secara umum, pandangan instrumtalis mempersepsikan bahwa identitas, pada prinsipnya, merupakan hal yang rasional. Dalam melihat pandangan instrumentalisme, terdapat dua perspektif yang dapat digunakan sebagai rujukan. Dua perspektif tersebut, masing-masing ialah perpektif elit dan perspektif social engineering.

Perspektif pertama ialah instrumentalisme persepektif elit. Dalam melihat hal ini, seringkali merujuk kepada pandangan Paul Brass yang menekankan peran para elit dalam suatu kelompok sosial dalam pembentukan identitas kolektif. Paul Brass berpendapat bahwa para elite dan counter-elites dalam suatu kelompok sosial memilih beberapa aspek dalam kebudayaan kelompok tersebut yang kemudian dikaitkan dengan nilai dan makna baru sehingga dapat digunakan sebagai simbol untuk memobilisasi kelompok terkait dalam rangka mempertahankan kepentingan dan berkompetisi dengan kelompok sosial lainnya (Brass, 1991). Merujuk kepada pendapat Paul Brass tersebut, insturmenalisme elit dalam pembentukan identitas kolektif setidaknya menunjukan dua hal. Pertama, dalam pembentukan identitas kolektif perlu terdapat artefak yang sudah ada sebelumnya, sehingga para elite dalam suatu kelompok sosial dapat membentuk ulang nilai-nilai tersebut. Kedua, beberapa simbol yang dibentuk oleh elite dalam suatu kelompok sosial dalam rangka membentuk identitas kolektif tidak serta merta melahirkan keterikatan yang dalam terhadap seluruh individu-individu dalam kelompok sosial tertentu. Hal tersebut diakrenakan bahwa sebagian besar simbol dan atribut sosial memiliki makna yang esoterik, sehingga pemaknaan terhadap simbol tersebut pun tidak setara. Hal tersebut yang kemudian merujuk para elite dalam suatu kelompok sosial perlu lebih selektif dalam memilih atribut sosial atau kebudayaan yang paling relevan untuk dibentuk 
ulang dalam rangka membentuk identitas kolektif dalam suatu kelompok sosial (Brass, 1991).

Persepktif kedua dalam pandangan instrumentalisme ialah perspektif socialengineering. Berbeda dengan perspektif elit yang melihat pembentukan identitas kolektif secara top-down, perspektif social-engineering melihat bahwa pembentukan identitas kolektif merupakan hasil dari tradisi yang dibentuk secara intensional oleh kelompok sosial tertentu. Dalam pandangan Eric Hobsbawn, tradisi yang dibentuk secara intensional merujuk kepada serangkaian praktik yang diterima dan dijalankan secara terbuka melalui ritual atau simbol tertentu (Hobsbawn, 2012). Ritual dan simbol tersebut dalam hal ini bertujuan untuk menanamkan nilai dan norma tertentu,melalui perilaku dan repetisi sehingga secara otomatis menciptakan pemahaman yang sama di antara individu dalam suatu kelompok sosial (Hobsbawn, 2012). Syarat utama hal tersebut dapat diterima secara terbuka oleh individu-individu di dalam suatu kelompok sosial, simbol dan ritual tertentu perlu memiliki aspek signifikansi historis sehingga pemaknaan akan hal tersebut dapat memiliki relevansi terhadap individu-individu di dalam kelompok sosial terkait. Dengan kata lain, signifikansi historis dari sebuah simbol dan ritual yang kemudian menjadi fondasi dasar dari sebuah tradisi, yang mana kemudian akan selalu berjalan beriringan dengan legitimasi dari individu-idividu di dalamnya dan sejauh mana hal tersebut mampu merepresentasikan identitas kolektif dari suatu kelompok sosial (Hobsbawn, 2012).

Merujuk kepada beberapa pespektif di atas, nasionalisme yang konotasinya merujuk kepad identitas kolektif suatu bangsa dalam suatu negara dapat lahir dari berbagai macam mode. Dalam hal ini, lembaga-lembaga negara memiliki kemampuan untuk menciptakan, memelihara, ataupun memodifikasi atribut-atribut sosial untuk kemudian diberikan nilai dan makna baru dalam rangka menciptakan identitas kolektif di tingkatan negara. Identitas kolektif di tingkatan negara tersebut yang pada akhirnya memiliki korelasi erat dengan pembentukan konsep nasionalisme dan kedaualatan dalam struktur sosial masyarakat di seluruh dunia, terutama jika merujuk kepada negara-negara westphalian hari ini. 
Studi Komparasi: Telaah Nasionalisme...

\section{Analisis Komparasi ‘Nation’ dalam Perspektif Islam dengan ‘Nation’ dalam Perspektif Barat}

Berdasarkan uraian di atas, terdapat kontradiksi dengan apa yang dianggap sebagai sebuah nation pada negara-negara Islam dengan nasionalisme dalam persepktif barat. Dalam pandangan kontemporer, nasionalisme memiliki keterkaitan dengan nation (Goldstein \& Pevehouse, 2014), namun hal tersebut berbeda dalam perspektif politik Islam, baik pada pendekatan Islam klasik maupun modern. Konsep nation dalam perspektif Islam adalah satuan-satuan kelompok etnis yang dibagi berdasarkan latar belakang agama. Seperti yang telah dijelaskan sebelumnya bahwa Kekaisaran Ottoman membedakan kelompok etnis muslim, kelompok etnis nasrani, kelompok etnis Yahudi menjadi nation yang berbeda-beda. Sehingga, dalam suatu negara terdapat banyak nation yang bahkan diberikan otonomi untuk memiliki pemimpin lokal yang biasanya adalah pemimpin agama dan diperbolehkan untuk hidup sesuai dengan aturan/hukum agama masing-masing. Adapun dalam pandangan barat, Erikson mengemukakan bahwa a nation is an ideological construction seeking to forge a link between cultural groups and the state. (Sabhlok, 2002)

Definisi di atas menggambarkan bahwa nation merupakan sebuah konstruksi ideologi yang berusaha untuk menghubungkan antara kelompok-kelompok kebudayaan dengan negara. Artinya, nation merupakan jembatan yang menghubungkan kelompok kebudayaan/etnis dengan lingkungan eksternal mereka dalam upaya menumbuhkan keterikatan pada state atau negara. Distingsi pemahaman mengenai nation sangat mencolok di antara kedua perspektif tersebut. Dalam pandangan Islam, nation berarti pembedaan kelompok masyarakat karena cara yang berbeda dalam menjalani hidup berdasarkan agama masing-masing. Sementara pandangan barat menganggap nation sebagai alat persatuan dalam membangun negara.

Penulis menganalisis bahwa perbedaan dalam memahami nation berujung pada konsekuensi di mana sebagaian besar cendekiawan dan tokoh politik Islam modern menolak konsep nasionalisme. Nasionalisme merupakan ideologi yang memiliki kekuatan untuk mengikat kelompok yang berbeda-beda ke dalam suatu teritorial yang dibentuk secara politis (Sabhlok, 2002). Nasionalisme dianggap bertentangan dengan prinsip Islam. Negara Islam haruslah mengedepankan prinsip- 
prinsip keagamaan sebagai fondasi negara. Hamdi Yazir yang merupakan ahli hukum Islam terkemuka di Turki mengemukakan kebangsaan adalah kepribadian yang terdiri atas elemen dan kesadaran sosial, bahwa agama adalah kesadaran sosialnya dan negara merupakan perwujudan dari hal tersebut (Ataman, 2003).

Pada beberapa titik, nasionalisme dianggap sebagai ancaman. Khomeini menyebutkan bahwa siapa saja yang menginginkan kebangkitan nasionalisme berarti ia menentang Islam. serupa dengan hal tersebut, Hawwa mengemukakan bahwa afiliasi etnis seseorang tidak boleh mempengaruhi keyakinannya yang dianggap sebagai kesalahan besar dan bila hal tersebut terjadi maka nasionalisme akan menggantikan Islam. Lebih jauh, nasionalisme berbenturan dengan ummah. Konsep nasionalisme digunakan dalam rangka menyatukan berbagai kelompok yang berbeda dalam satu naungan negara. Adapun konsep ummah tidak mengenal batas-batas geografis yang menjadi pemisah antara kelompok-kelompok etnis muslim yang berbeda. Seluruh kelompok muslim dianggap sebagai satu kesatuan dalam sebuah nation.

Pada realitanya, sejarah memang mencatat bahwa pada masa-masa tertentu golongan nasionalisme dan kelompok keagamaan menyatukan kekuatan seperti pada masa perang kemerdekaan Iran yang dipimpin oleh Kemal Ataturk untuk melawan invasi asing ke Turki yang dianggap sebagai tanah bagi orang muslim. Namun, setelah ia berhasil merebut kekuasaan, kelompok-kelompok etnis seperti Kurdi, Laze, serta Arab tidak diakui identitasnya. Beberapa cendekiawan muslim juga tidak sepenuhnya menolak nasionalisme asalkan ia bersesuaian dengan prinsip-prinsip Islam. Bahkan ada yang menganggap bahwa penyatuan antara nasionalisme dan Islam sebagai solusi bagi permasalahan dalam dunia Islam.

Pernyataan beberapa cendekiawan muslim yang setuju atas konsep nasionalisme di atas akan dianalisis dengan teori imagined community oleh Benedict Anderson. Anderson mengemukakan bahwa nation atau bangsa adalah suatu komunitas terbayang yang secara inheren terbatas dan berdaulat (Anderson, 2006). Dikatakan sebagai komunitas yang dibayangkan karena tidak semua anggota dari kelompok/bangsa tersebut dapat mengetahui dan mengenal satu sama lain secara keseluruhan, sekalipun bagi komunitas yang kecil. Adapun konsep nasionalisme sebagai pembentuk suatu negara bagi Anderson bukanlah sebuah isme atau ideologi. la lebih memilih untuk menghubungkannya dengan kekerabatan (kinship) atau agama 
(religion). Sampai pada pemahaman ini, maka ditemukan titik persinggungan tentang nasionalisme diantara dua pandangan yang berbeda di atas.

Anderson mengemukakan bahwa nasionalisme menjadi penting ketika identitas-identitas lama sudah mulai kehilangan kemampuannya untuk mempersatukan. Namun, ia menegaskan bahwa:

"I am not claiming that the appearance of nationalism towards the end of the eighteenth century was 'produced' by the erosion of religious certainties... . Nor am I suggesting that somehow nationalism historically 'supersedes' religion. What I am proposing is that nationalism has to be understood by aligning it, not with self- consciously held political ideologies, but with the large cultural systems that preceded it, out of which - as well as against which - it came into being." (Anderson, 2006)

Berdasarkan pernyataan di atas, Anderson memberikan poin bahwa nasionalisme yang dipahami sebagai produk Barat justru lahir dari kondisi peradaban sebelumnya yang sudah tidak kredibel dalam hal persatuan. la tidak muncul begitu saja, melainkan hadirnya nasionalisme sebagai konsekuensi dari sistem budaya yang mendahuluinya, bahkan dari yang menentang adanya nasionalisme. Ketika sebagian besar cendekiawan muslim modern menganggap nasionalisme sebagai ancaman, Anderson justru tidak menyarankan kehadiran nasionalisme sebagai pengganti agama.

Anderson justru menyarankan agar nasionalisme bisa dipahami selaras dengan realitas dan tidak dilihat sebabagi ideologi yang berdiri sendiri. Seperti yang telah disebutkan sebelumnya, bahwa Nursi membagi nasionalisme menjadi 2 yakni nasionalisme positif serta negatif. Bagi Nursi, nasionalisme positif justru kompatibel dengan agama dengan meningkatkan solidaritas dan kerjasama di kalangan komunitas serta meningkatkan persaudaraan antar muslim. Namun yang harus dihindari adalah nasionalisme negatif dimana hal tersebut justru menimbukan rasisme dan permusuhan satu sama lain yang ia sebut sebagai European Diesease. Uraian di atas, merefleksikan bahwa pemikiran Anderson selaras dengan beberapa cendekiawan muslim yang setuju dengan konsep nasionalisme. 
Wahyu Rozzaqi Ginanjar

\section{Kesimpulan}

Dalam sejarah peradaban Islam klasik, pemikiran dan praktik akan keberagaman etnis dalam perspektif Islam bersifat liberal. Kelompok etnis muslim maupun non muslim diperlakukan setara dan dibebaskan untuk hidup berdasarkan kebudayaan serta ajaran agama masing-masing. Lebih dari itu, negara Islam memperbolehkan kelompok etnis non muslim untuk mempraktikkan hukum mereka bagi para anggota kelompoknya masing-masing yang dianggap sebagai sebuah nation.

Meskipun demikian, yang terjadi di negara muslim modern justru berkebalikan dengan hal tersebut. Cendekiawan dan tokoh pergerakan pada Muslim nation-state meninggalkan realita historisnya. Pendekataan ini menyebabkan terjadinya penolakan akan konsep nasionalisme yang dipahami sebagai pandangan Barat. Mereka menempatkan nasionalisme dengan prinsip Islam dalam posisi biner dan tidak sesuai dengan paham Islam.

Namun demikian, tidak semua cendekiawan muslim modern menolak konsep nasionalisme. Pemahaman akan prinsip-prinsip Islam mengenai etnisitas dan nasionalisme dianggap membantu Muslim nation-state untuk memelihara dan menumbuhkan keragaman kelompok etnis yang dimiliki. Gagasan ini justru berkenaan dengan apa yang ditawarkan Anderson terkait nasionalisme dan agama.

\section{Daftar Pustaka}

Anderson, B. (2006). Imagined Communities: Reflection on the Origin and Spread of Nationalism. In English (3rd ed.). London: Verso.

Ataman, M. (2003). Islamic Perspective on Ethnicity and Nationalism: Diversity or Uniformity? Journal of Muslim Minority Affairs, 23(1), 89-102. https://doi.org/10.1080/13602000305929

Brass, P. R. (1991). Ethnicity and Nationalism: Theory and Comparison. In Ethnicity and Nationalism: Theory and Comparison (1st ed.). New Delhi: Sage Publications.

Conversi, D. (1995). Reassessing current theories of nationalism: Nationalism as boundary maintenance and creation. Nationalism and Ethnic Politics, 1(1), 7385. https://doi.org/10.1080/13537119508428421

Formichi, C. (2010). Pan-Islam and Religious Nationalism: The Case of Kartosuwiryo and Negara Islam Indonesia. Indonesia, (90), 125-146. Retrieved from 
Studi Komparasi: Telaah Nasionalisme...

http://cip.cornell.edu/DPubS? service=UI\&version=1.0\&verb=Display \&page $=$ rec ord\&handle=seap.indo/1286985934

Geertz, C. (1973). The Interpretation Of Cultures. In The Interpretation Of Cultures (1st ed.). New York: Basic Books.

Goldstein, J. S., \& Pevehouse, J. C. (2014). International Relations: TENTH EDITION 2013 - 2014 UPDATE. Boston: Pearson.

Haddad, R. M. (1983). Yvonne Yazbeck Haddad. Contemporary Islam and the Challenge of History. Albany: SUNY Press, 1982. 272 pp. \$33.50. Middle East Studies Association Bulletin, 17(2), 217-218. https://doi.org/10.1017/S0026318400013535

Hobsbawn, E. (2012). The Invention of Tradition. In E. Hobsbawm \& T. Ranger (Eds.), The Invention of Tradition. https://doi.org/10.1017/CBO9781107295636

Lambton, A. K. S. (2013). State and Government in Medieval Islam. In Asian Journal of Middle Eastern and Islamic Studies (Vol. 11). https://doi.org/10.4324/9780203385463

Naqvi, A. M. (1998). Islam and Nationalism. In A. Pazargadi (Ed.), Islam and Nationalism (1st ed.). https://doi.org/10.2307/j.ctt18fs3rt.8

Owen, R. (1988). Islam in a world of nation-states. History of European Ideas, 9(3), 349-351. https://doi.org/10.1016/0191-6599(88)90184-2

Rajaee, F. (1988). Islam in a World of Nation-States. By James Piscatori (New York: Cambridge University Press in association with the Royal Institute of International Affairs, 1984 . viii, 193p. \$34.50, cloth; $\$ 12.95$, paper). American Political Science Review, 82(2), 683-684. https://doi.org/10.2307/1957467

Riddell, R. (1982). Book Reviews : Faith and Power: The Politics of Islam Edward Mortimer Faber. International Relations, 7(4), 2251-2252. https://doi.org/10.1177/004711788200700419

Sabhlok, S. G. (2002). Nationalism and ethnicity and the nation-state in South Asia. Nationalism and Ethnic Politics, 8(3), 24-42. https://doi.org/10.1080/13537110208428668

Saeed, A. (1999). Rethinking citizenship rights of non-muslims in an islamic state: Rashid al-ghannūshi's contribution to the evolving debate. International Journal of Phytoremediation, 21(1), 307-323. https://doi.org/10.1080/09596419908721189

Sayegh, P. Y. (2011). Religion and Nationalism in Contemporary Europe: Towards a Renewed Syncretism? 1-33. Retrieved from http://goo.gl/wLr38Z

Soper, J. C., \& Fetzer, J. S. (2018). A Theory of Religion and Nationalism. In 
Wahyu Rozzaqi Ginanjar

Religion and Nationalism in Global Perspective.

https://doi.org/10.1017/9781316995280.002

van Den Berghe, P. L. (1987). The Ethnic Phenomenon. In The Ethnic Phenomenon (Revised). Westport: Greenwood Press.

Zubaida, S. (2004). Islam and nationalism: continuities and contradictions*. Nations and Nationalism, 10(4), 407-420. https://doi.org/10.1111/j.1354-

5078.2004.00174.x

132 | Komunitas Vol. 11, No. 2 (2020) 